\title{
DETERMINAN SHOPPING OPINION: PERSPEKTIF KLIEN DAN KANTOR AKUNTAN PUBLIK
}

\author{
Alfina Dhia Ulfa, Sulhani Sulhani* \\ Institut Agama Islam Tazkia, Bogor, Indonesia \\ alfinadhiaulfa@gmail.com, sulhani@tazkia.ac.id \\ https://doi.org/10.46367/jas.v5i1.328
}

Received: Apr 26, 2021 Revised: Jun 05, 2021 Accepted: Jun 16, 2021 Published: Jun 28, 2021

\begin{abstract}
This study analyzes the effect of audit market competition, client size, and financial distress on shopping opinions. The sample used in this study is a manufacturing company listed on the Indonesia Stock Exchange for 2016 to 2017. The data used in the study were 76 data from the company's annual reports. The data analysis method used was binary logistic regression. This study indicates that audit market competition and client size do not affect shopping opinion practices. However, financial distress has a significant positive effect on the tendency to practice shopping opinion. This indicates that a company with an excellent financial condition chooses to change its auditor compared to the same auditor; this is done because financially, the company can change public accounting.
\end{abstract}

Keywords: Audit Market Concentration, Financial Distress, Shopping Opinion.

\begin{abstract}
ABSTRAK
Penelitian ini bertujuan untuk menganalisis pengaruh kompetisi pasar audit, ukuran klien, dan financial distress terhadap shopping opinion. Sampel yang digunakan dalam penelitian ini adalah Perusahaan Manufaktur yang terdaftar pada Bursa Efek Indonesia periode 2016-2017. Data yang digunakan dalam penelitian sebanyak 76 data yang berasal dari laporan tahunan perusahaan. Metode analisis data yang digunakan adalah regresi logistik biner. Hasil penelitian ini menunjukkan bahwa kompetisi pasar audit dan ukuran klien tidak berpengaruh terhadap praktik shopping opinion. Namun, financial distress berpengaruh positif signifikan terhadap kecenderungan melakukan praktik shopping opinion. Hal ini mengindikasikan bahwa perusahaan yang memiliki kondisi keuangan yang baik memilih untuk mengganti auditornya dibandingkan dengan bertahan pada auditor yang sama, hal ini dilakukan karena secara keuangan perusahaan memiliki sumber daya tersebut untuk berganti kantor akuntan publik.
\end{abstract}

Kata kunci: Kompetisi Pasar Audit, Kesulitan Keuangan, Shopping Opinion.

\section{PENDAHULUAN}

Shopping opinion terjadi ketika perusahaan menginginkan opini audit yang lebih baik untuk memberikan citra yang baik kepada pengguna laporan keuangan. Perusahaan melakukan jual beli opini audit dengan cara mempengaruhi keputusan 
auditor untuk mendapatkan opini yang lebih baik dari opini sebelumnya. Shopping opinion dapat menyebabkan melemahnya perlindungan audit atas investor. Hal ini dikarenakan auditor memberikan opini audit yang lebih baik atas kualitas laporan keuangan perusahaan yang rendah. Menurut Chung et al. (2019) shopping opinion sering terjadi pada perusahaan yang mengalami kegagalan dalam pelaporan keuangan dan akan berdampak pada penurunan kualitas audit. Perusahaan akan menaikkan biaya audit untuk mendapatkan opini yang lebih baik tanpa mengganti auditor sebelumnya sehingga kepercayaan investor tetap baik. Sedangkan menurut Chen, Francis, and Hou (2017), perusahaan cenderung melakukan praktik shopping opinion dengan mengganti auditor sebelumnya dan melakukan perikatan dengan auditor yang baru dengan biaya audit yang lebih tinggi untuk memperoleh opini audit yang lebih baik. Namun disisi lain, adanya kenaikan biaya audit juga merupakan dampak dari peningkatan konsentrasi pasar audit (Huang, Chang, and Chiou 2016). Hal ini disebabkan karena banyak perusahaan cenderung hanya terpusat pada kantor akuntan publik (KAP) yang bereputasi saja. Sehingga KAP dapat menaikkan biaya audit sesuai dengan keingingan KAP.

Di Indonesia tingkat konsentrasi pasar jasa audit terbilang cukup tinggi. Hal ini dibuktikan oleh penelitian Afriansyah and Siregar (2010) yang menunjukkan bahwa di Indonesia terdapat empat KAP besar yang merupakan affiliasi dari KAP big four internasional. Dengan menggunakan pengukuran atas total aset klien audit dinyatakan bahwa empat KAP yang berafiliasi dengan KAP big four internasional di tahun 2000 menguasai 94\% pasar audit yang ada di Indonesia yang kemudian mengalami penurunan menjadi $86 \%$ ditahun 2002 lalu naik kembali menjadi 88\% ditahun 2005. Angka ini menunjukan bahwa pasar jasa audit di Indonesia memiliki tingkat konsentrasi yang tinggi yaitu terkonsentrasi pada KAP big four. Adanya konsentrasi audit menyebabkan terpusatnya perhatian perusahaan kepada KAP big four internasional. Sehingga, mengakibatkan KAP non big four tidak mendapatkan klien dan menggunakan segala cara untuk mendapatkan klien, termasuk melakukan praktik shopping opinion. Kondisi tersebut juga meningkatkan kompetisi pasar audit yang tinggi antar KAP non big four yang dapat mengakibatkan terjadinya penurunan biaya audit dan shopping opinion. Hal ini didukung oleh penelitian Xue, Yao, and Wang (2018) yang menyatakan bahwa kompetisi pasar audit yang tinggi dapat menyebabkan terjadinya shopping opinion. Karena setiap KAP harus bersaing dengan KAP lain untuk mendapatkan klien dan hal ini dapat menyebabkan adanya kesetaraan antara KAP dan klien.

Sedangkan menurut Winata and Anisykurlillah (2018) perusahaan besar memiliki tingkat perubahan auditor yang jauh lebih rendah daripada perusahaan kecil. Karena perusahan besar memiliki kemampuan untuk membayar auditor dengan biaya yang lebih tinggi. Sehingga, dapat menekan KAP untuk memberikan opini yang lebih baik. Kondisi tersebut sering dikenal dengan istilah praktik internal shopping opinion (Chen, Francis, and Hou 2017). Hasil penelitian Manto and Wanda (2018) menyatakan bahwa perusahaan yang mengalami kesulitan keuangan cenderung untuk melakukan pergantian auditor agar mendapatkan auditor dengan biaya yang lebih rendah. Menurut Ardi, Saputra, and Mulyani (2019) perusahaan yang mengalami financial distress cenderung menerima opini audit going-concern. Menurut Laksmiati and Atiningsih (2018) 
ketika perusahaan menerima opini audit going concern, perusahaan akan melakukan pergantian auditor untuk menghindari penerimaan opini audit going concern, sehingga terjadi praktik shopping opinion untuk perusahaan yang mengalami masalah keuangan (financial distress). Penelitian ini berbeda dari penelitian sebelumnya, karena shopping opinion dalam penelitian ini diukur dengan mempertimbangkan adanya internal dan eksternal shopping opinion yang terjadi di Indonesia. Selain itu penelitian-penelitian sebelumnya terkait dengan shopping opinion tidak mengaitkan pergantian auditor dengan ada atau tidaknya kenaikan biaya audit (Achyarsyah 2016).

Penelitian ini bertujuan untuk menganalisis faktor internal perusahaan yaitu ukuran perusahaan dan kondisi keuangan terhadap kecenderungan perusahaan untuk melakukan shopping opinion. Selain itu penelitian ini juga bertujuan untuk menganalisis faktor eksternal yaitu konsentrasi pasar audit terhadap kecenderungan penerimaan shopping opinion. Hal ini untuk membuktikan apakah independensi auditor terpengaruh oleh ketatnya persaingan pasar audit non big four dengan menerima praktik shopping opinion yang dilakukan oleh perusahaan.

\section{TELAAH LITERATUR}

\section{Agency Theory dan Shopping Opinion}

Teori agensi adalah pengembangan dari suatu teori yang mempelajari suatu desain kontrak dimana para agen bekerja atau bertugas atas nama principal ketika keinginan atau tujuan mereka bertolak belakang maka akan terjadi suatu konflik (Jensen and Meckling 1976). Hanya perbedaan kepentingan antara manajemen dan pihak-pihak utama yang terkait dapat menyebabkan adanya konflik keagenan dimana agen tersebut akan berusaha memaksimalkan kepentingan sendiri yang dapat merugikan pihak utama (Jensen and Meckling 1976). Sehingga, diperlukan adanya audit untuk menjamin penyusunan laporan keuangan. Selanjutnya, hubungan antara pihak manajemen dan auditor juga dapat menyebabkan konflik keagenan. Auditor seharusnya bersifat independen dan mengutamakan kepentingan publik, akan tetapi auditor juga memiliki kepentingan pribadi untuk mempertahankan loyalitas klien, yaitu business entity (Ouyang and Wan 2013). Independensi auditor dapat diragukan karena auditor dipilih dan dibayar oleh manajemen perusahaan yang diaudit (Fachruddin and Handayani 2017). Hal ini dapat menyebabkan adanya ketergantungan antara auditor dengan pihak manajemen, dimana dapat memberikan tekanan kepada auditor terkait dengan keputusan auditor dan hasil audit yang dilakukan oleh auditor atas negosiasi dengan manajemen dalam bentuk shopping opinion (Yakubu and Williams 2020; Su 2009).

\section{Low Balling Theory dan Shopping Opinion}

DeAngelo (1981) merupakan peneliti pertama yang melakukan penelitian dalam topik praktik low balling. Dalam penelitiannya menyatakan bahwa praktik low balling adalah negosiasi pada awal penugasan audit yang sudah dipertimbangkan secara wajar untuk keuntungan dari segi biaya atas kompetitor audit di masa yang akan datang. Keuntungan tersebut terjadi dikarenakan adanya start-up biaya yang signifikan dalam teknologi audit dan biaya transaksi atas 
pergantian auditor. Ketika auditor sudah menerima biaya audit pada perikatan pertama, auditor tersebut kemudian menaikkan biaya audit tersebut di masa yang akan datang atas jasa audit yang telah dilakukan oleh auditor.

Low-balling atau penurunan biaya audit merupakan akibat dari adanya peningkatan kompetisi pasar audit (Bleibtreu and Stefani 2018). Tingkat kompetisi yang tinggi dapat menyebabkan kesetaraan antara KAP dan klien. KAP menurunkan biaya auditnya agar memudahkan KAP tersebut untuk mendapatkan klien. Sehingga, memungkinkan KAP untuk memberikan opini yang lebih baik demi menarik klien. Kompetisi pasar audit yang tinggi, akan mengakibatkan terjadinya beberapa hal, seperti praktik low-balling dan shopping opinion (Bleibtreu and Stefani 2018).

\section{Shopping Opinion}

Menurut Chen et al. (2015) salah satu cara untuk melakukan shopping opinion adalah dengan melakukan pergantian auditor (auditor switching). Hasil penelitian Laksmiati and Atiningsih (2018) menyatakan bahwa suatu perusahaan melakukan pergantian auditor untuk menghindari penerimaan opini going concern dengan dua cara pertama, jika seorang auditor bekerja pada perusahaan tertentu, perusahaan dapat mengancam melakukan pergantian auditor. Kedua, bahkan ketika auditor yang bersangkutan independen, perusahaan akan memberhentikan akuntan publik (auditor) yang cenderung memberikan opini going concern. Sedangkan, menurut Sangkrista and Fitriany (2017) cara untuk melakukan shopping opinion adalah dengan membeli opini auditor. Hal ini dilakukan dengan cara memberikan imbal jasa audit atau biaya audit yang lebih tinggi kepada auditor atas proses audit yang telah dilakukan.

\section{Kompetisi Pasar Audit}

Menurut Chung et al. (2019) konsentrasi pasar audit dapat menurunkan fee audit namun tetap menaikan kualitas audit. Hasil penelitian Afriansyah and Siregar (2010) menunjukkan bahwa struktur pasar audit di Indonesia mengalami perubahan dari yang sebelumnya dominan (monopoli) menjadi oligopoli. Namun, bentuk pasar audit di Indonesia memiliki perbedaan jika pendekatan penghitunganya menggunakan jumlah total aset klien dan jumlah klien audit. Ketika menggunakan jumlah klien audit, menunjukkan bahwa pasar audit adalah oligopoli lemah dan ketika menggunakan jumlah total aset menunjukkan bahwa pasar audit di Indonesia adalah oligopoli kuat. Sedangkan, hasil penelitian Anggraita et al. (2016) menunjukkan bahwa struktur pasar jasa audit di Indonesia adalah oligopoli lemah karena 4 perusahaan memiliki kurang dari $40 \%$ pangsa pasar, kecuali untuk industri pertambangan adalah oligopoli kuat yang memiliki 4 perusahaan dengan pangsa pasar lebih dari $40 \%$.

\section{Client Size}

Menurut Winata and Anisykurlillah (2018) shopping opinion terkait dengan client size (ukuran klien/perusahaan) ada dua, yaitu internal shopping opinion dan external shopping opinion. Terdapat korelasi positif antara ukuran klien dan internal shopping opinion. Perusahaan berukuran besar lebih cenderung melakukan internal shopping opinion, karena perusahaan besar mampu melakukan negosiasi ulang dengan auditor sebelumnya untuk membuat perjanjian 
atau perikatan (Chen, Francis, and Hou 2017). Hal ini dilakukan dengan membuat perjanjian dan perikatan baru dengan cara menaikkan biaya auditnya tanpa harus mengubah auditornya. Selain itu, perusahaan berukuran kecil yang cenderung untuk melakukan external shopping opinion dengan cara melakukan pergantian auditor. Perusahaan berukuran besar juga dapat melakukan external shopping opinion, ketika perusahaan tidak mendapatkan opini yang menguntungkan. Sehingga, menyebabkan perusahaan tersebut harus berganti auditor (Darmayanti 2017).

\section{Financial Distress}

Konsep financial distress dan financial bankruptcy memiliki makna yang sama. Kebangkrutan adalah fakta penting kehidupan di lingkungan bisnis saat ini. Kebangkrutan terjadi ketika perusahaan tidak dapat memenuhi kewajibannya dan berlaku untuk periode keringanan dalam menata ulang hutangnya atau untuk melikuidasi asetnya (Bryan, Fernando, and Tripathy 2013). Dampak buruk dari terjadinya financial distress pada perusahaan adalah menurunnya jumlah nasabah (John and Ogechukwu 2018). Menurut penelitian John and Ogechukwu (2018) salah satu penyebab terjadinya financial distress adalah buruknya mekanisme tata kelola perusahaan.

\section{Pengaruh Kompetisi Pasar Audit terhadap Shopping Opinion}

Menurut Bleibtreu and Stefani (2018) dengan kompetisi pasar audit yang tinggi, dapat mengakibatkan terjadinya praktik shopping opinion. Hal ini dapat terjadi karena persaingan yang tinggi antar KAP dapat mengakibatkan sulitnya KAP untuk mendapatkan klien, sehingga KAP cenderung mengikuti keinginan klien demi mempertahankan klien mereka. Switching auditor terjadi jika KAP sebelumnya memberikan opini yang tidak sesuai dengan keinginan klien, sehingga klien lebih memilih untuk mengganti dengan KAP yang akan memberikan opini yang lebih baik dari KAP sebelumnya. Hal tersebut juga didukung oleh hasil penelitian May (2016) yang menemukan bahwa peningkatan kompetisi pasar audit menyebabkan meningkatnya peluang klien untuk berganti auditor dan memilih auditor dengan biaya yang lebih rendah. Selanjutnya, menurut Newton et al. (2016) terdapat hubungan yang kuat antara shopping opinion dan kompetisi pasar audit untuk KAP big four. Berdasarkan uraian tersebut maka dapat diajukan hipotesis sebagai berikut:

H1: Kompetisi pasar audit berpengaruh terhadap kecenderungan melakukan praktik shopping opinion.

\section{Pengaruh Client Size terhadap Shopping Opinion}

Client Size (ukuran klien/perusahaan) sering dikaitkan dengan kualitas informasi akuntansi. Hal ini dikarenakan perusahaan kecil cenderung tidak memiliki sistem pelaporan yang memadai untuk menghadapi terjadinya perubahan standar akuntansi dan sebaliknya perusahaan besar memiliki sumber daya yang sangat memadai untuk melakukan pelaporan yang berkualitas. Hal ini didukung oleh penelitian Fathi (2013) yang menyatakan bahwa perusahaan berukuran kecil cenderung memiliki kualitas sistem informasi akuntansi yang rendah. Sehingga akan berdampak pada penerimaan opini audit yang berkualitas rendah jika dibandingkan dengan perusahaan besar. Hasil penelitian Darmayanti (2017) 
menyatakan bahwa perusahaan berukuran kecil cenderung untuk melakukan pergantian auditor untuk menghindari opini audit yang tidak baik, supaya dapat menjaga kepercayaan investor dan kreditor. Selanjutnya, menurut penelitian Winata and Anisykurlillah (2018) perusahaan besar memiliki tingkat perubahan auditor yang jauh lebih rendah daripada perusahaan kecil. Karena perusahan besar memiliki kemampuan untuk membayar jasa audit dengan nilai yang lebih tinggi. Sehingga, dapat menekan KAP untuk memberikan opini yang lebih baik. Sedangkan untuk perusahaan-perusahaan kecil dengan nilai total aset yang rendah cenderung untuk beralih ke KAP non big four (Darmayanti 2017). Berdasarkan uraian tersebut maka dapat diajukan hipotesis sebagai berikut:

H2: Client size tidak berpengaruh terhadap kecenderungan melakukan praktik shopping opinion.

\section{Pengaruh Financial Distress terhadap Shopping Opinion}

Perusahaan yang mengalami financial distress atau masalah keuangan lebih cenderung mengganti KAP dibandingkan dengan perusahaan yang lebih sehat karena perusahaan seperti ini perlu menggunakan KAP dengan kualitas yang lebih tinggi untuk mempertahankan citra baik perusahaan dimata investor (Manto and Wanda 2018). Sejalan dengan hasil penelitian Kurnia and Mella (2018) perusahaan yang mengalami financial distress cenderung untuk mengganti KAP untuk menghindari kemungkinan diperolehnya opini going concern. Selanjutnya, menurut Suyono, Yi, and Riswan (2013) kondisi keuangan klien mempengaruhi audit switching. Karena kondisi keuangan menggambarkan pertumbuhan perusahaan. Perusahaan akan memilih berpindah auditor yang lebih bereputasi untuk meningkatkan kepercayaan pengguna laporan keuangan. Berdasarkan uraian tersebut maka dapat diajukan hipotesis sebagai berikut:

H3: Financial distress berpengaruh terhadap kecenderungan melakukan praktik shopping opinion.

\section{METODE PENELITIAN}

Penelitian ini merupakan penelitian deskriptif kuantitatif dengan tujuan untuk menganalisis pengaruh kompetisi pasar audit, ukuran klien, dan financial distress terhadap shopping opinion. Pengambilan sampel pada penelitian ini menggunakan teknik purposive sampling, yaitu pengambilan sampel berdasarkan kriteria yang telah ditetapkan agar sesuai dengan tujuan penelitian. Sampel dalam penelitian ini adalah perusahaan manufaktur yang menggunakan mata uang rupiah dan perusahaan manufaktur yang mencantumkan biaya audit dari tahun 2016 sampai dengan 2017.

Variabel dependen dalam penelitian ini adalah shopping opinion. Pengukuran Shopping opinion dalam penelitian ini dimodifikasi dari penelitian Chen, Francis, and Hou (2017) bahwa terdapat dua jenis shopping opinion yaitu internal shopping opinion dan eksternal shopping opinion. Pengukuran shopping opinion dalam penelitian ini adalah: pemberian nilai 1, jika variabel shopping opinion termasuk kedalam salah satu kriteria berikut: (a) Perusahaan melakukan audit switching, adanya kenaikan biaya audit, dan opini audit wajar tanpa pengecualian. (b) Perusahaan melakukan audit switching, adanya kenaikan biaya audit, dan opini audit naik atau lebih baik. (c) Perusahaan tidak melakukan audit 
switching, adanya kenaikan biaya audit, dan opini audit wajar tanpa pengecualian. (d) Perusahaan melakukan audit switching, adanya biaya audit yang tetap, dan opini audit naik atau lebih baik. Selain itu diberi nilai 0 .

Variabel independen kompetisi pasar audit menggunakan herfindahl hirschman index (HHI). HHI digunakan untuk menguji tingkat persaingan antara industri yang satu dengan yang lain. Anggraita et al. (2016) melakukan penghitungan jumlah klien dan total aset dari klien pada tiap perusahaan yang terdaftar di Bursa Efek Indonesia, kemudian ditentukan pangsa pasar masingmasing KAP, yaitu:

Keterangan:

$$
\boldsymbol{H H I}=\sum_{t}\left(\frac{\text { Total Asset }_{\mathrm{i}}}{\text { Total Assetn }}\right)^{2}
$$

HHI : Nilai herfindahl hirschman index perusahaan $\mathrm{i}$

Total Asset $_{\mathrm{i}}$ : Nilai total aset perusahaan i

Total Asset ${ }_{n}$ : Nilai total aset klien KAPn

$H H I$ berada pada nilai 0 sampai 1 . Untuk pasar persaingan sempurna nilai $H H I$ berada pada nilai 0 dan pasar monopoli jika nilai mencapai 1 .

Variabel independen client size (ukuran klien atau perusahaan) merupakan suatu skala untuk mengklasifikasikan besar atau kecilnya suatu perusahaan. Total aset dipilih sebagai ukuran perusahaan karena nilai aset relatif stabil. Menurut Carcello and Nagy (2004), cara yang digunakan untuk mengukur variabel ukuran perusahaan adalah logaritma natural total asset. Jika dituliskan dalam bentuk rumus adalah sebagai berikut: Ukuran Perusahaan $($ Size $)=$ Log Natural (Total Asset).

Variabel independen financial distress menggunakan nilai Altman Z-Score (Altman 1968) karena model ini dapat diterapkan di semua sektor. Jika nilai ZScore lebih besar dari 2,99, maka perusahaan dikategorikan memiliki kondisi keuangan yang baik. Sedangkan jika nilai Z-Score lebih kecil dari 1,81, maka perusahaan dianggap memiliki kondisi keuangan yang buruk atau bahkan dapat mengarah pada kebangkrutan. Kemudian jika nilai Z-Score berada diantara 1,81 sampai 2,99, maka perusahaan dianggap berada pada zona abu-abu atau disebut sebagai zona ketidaktahuan atau zone of ignorance. Altman (1968) juga menyatakan bahwa zona abu-abu ini merupakan zona dimana perusahaan memiliki risiko kesulitan keuangan yang dapat berdampak pada kebangkrutan jika perusahaan tidak mampu melakukan perbaikan terhadap kinerja perusahaannya. Rumus untuk mencari nilai Altman Z-Score adalah sebagai berikut:

$$
\begin{aligned}
\mathrm{Z}=1.2 \times \frac{\text { Working Capital }}{\text { Total Assets }}+1.4 \times \frac{\text { Retained Earnings }}{\text { EBIT }} \\
+3.3 \times \frac{\text { Total Assets }}{\text { Total Assets }} \\
+0.6 \times \frac{\text { Market Value of Equity }}{\text { Book Value of Debt }} \\
+1.0 \times \frac{\text { Sales }}{\text { Total Assets }}
\end{aligned}
$$

Variabel kontrol dalam penelitian ini adalah tahun. Tahun digunakan bertujuan untuk mengendalikan faktor-faktor lain yang dapat mempengaruhi kecenderungan untuk melakukan praktik shopping opinion. 
Teknik analisis data dalam penelitian ini adalah menggunakan regresi logistik biner. Alasan penelitian ini menggunakan regresi logistik biner karena variabel dependen menggunakan skala nominal yang bersifat kualitatif dan variabel independennya menggunakan skala rasio. Sedangkan model penelitian yang digunakan dalam penelitian ini adalah sebagai berikut:

$$
\mathrm{SO}_{\mathrm{it}+1}(\text { prob }=0, \text { prob }=1)=\beta_{0}+\beta_{1} \mathrm{KPA}_{\mathrm{it}}+\beta_{2} \mathrm{CS}_{\mathrm{it}}+\beta_{3} \mathrm{FD}_{\mathrm{it}}+\beta_{4} \mathrm{Y}_{\mathrm{it}}+\mathrm{c}
$$

Keterangan:

$\begin{array}{ll}\text { SO } & : \text { Shopping Opinion } \\ \text { KPA } & : \text { Kompetisi Pasar Audit } \\ \text { CS } & : \text { Client Size } \\ \text { FD } & : \text { Financial Distress } \\ \text { Y } & : \text { Year (Tahun Pengamatan) } \\ \beta_{1}, \beta_{2}, \beta_{3} & : \text { Koefisien Regresi } \\ \epsilon & : \text { Standar Kesalahan (error) }\end{array}$

Setelah itu, dilakukan pengujian hipotesis untuk mengetahui keakuratan dan kebenaran dari hipotesis yang telah ditentukan yang mencakup uji parsial, uji serentak dengan likelihood ratio, dan goodnest of fit test dengan $R$-Square.

\section{HASIL DAN PEMBAHASAN PENELITIAN}

\section{Statistik Deskriptif}

Uji statistik deskriptif terhadap model penelitian kompetisi pasar audit, ukuran klien dan financial distress terhadap shopping opinion digunakan untuk melihat penyebaran data variabel-variabel yang digunakan dalam model tersebut. Hasil statisik deskriptif dari keempat variabel tersebut dapat dilihat pada Tabel 1.

Tabel 1 Statistik Deskriptif

\begin{tabular}{cccccc}
\hline Variabel & $\boldsymbol{N}$ & Mean & Std. Deviasi & Min. & Max. \\
\hline SO & 76 & 0,6315789 & 0,4855816 & 0 & 1 \\
KPA & 76 & 0,0144625 & 0,0237086 & 0,000000113 & 0,0685416 \\
CS & 76 & 28,45981 & 1,302952 & 25,90106 & 31,42035 \\
FD & 76 & 2,315121 & 1,362097 & $-2,474116$ & 6,914432 \\
\hline
\end{tabular}

Variabel shopping opinion memiliki mean (nilai rata-rata) sebesar 0,6315789 , nilai minimum sebesar 0 , nilai maksimum sebesar 1 dan nilai standar deviasi sebesar 0,4855816. Hal ini menunjukkan bahwa mayoritas perusahaan melakukan shopping opinion. Variabel kompetisi pasar audit merupakan kondisi keuangan perusahaan memiliki nilai rata-rata sebesar 0,0144625 dengan nilai minimum sebesar 0,000000113 , nilai maksimum sebesar 0,0685416 dan nilai standar deviasi sebesar 0,0237086. Variabel client size merupakan ukuran klien atau perusahaan. Besarnya ukuran klien atau perusahaan diukur dengan menggunakan logaritma natural total (Chen et al. 2015). Client size memiliki nilai minimum adalah perusahaan BTON, yaitu dengan nilai sebesar 25,90106, sedangkan, SMGR adalah perusahaan yang memiliki nilai maksimum yaitu sebesar 31,4203. Selanjutnya, dengan membandingkan nilai minimum dan maksimum, dapat dikatakan bahwa client size memiliki rentang data yang relatif besar. Client size memiliki nilai rata-rata sebesar 28,45981, dengan nilai standar deviasi sebesar 1,302952. Variabel financial distress merupakan kesulitan 
keuangan yang terjadi pada suatu perusahaan. Penelitian ini, menunjukkan bahwa perusahaan yang mengalami financial distress memiliki nilai minimum adalah perusahaan KBRI, yaitu dengan nilai sebesar -2,474116, sedangkan, SIDO adalah perusahaan yang memiliki nilai maksimum, karena memiliki nilai sebesar 6,914432. Variabel ini juga memiliki nilai rata-rata sebesar 2,315121, dengan nilai standar deviasi sebesar 1,362097.

\section{Uji Parsial}

Uji parsial atau uji statistik z dilakukan sebagai pengganti uji statistik t. Uji parsial digunakan untuk mengetahui seberapa jauh variabel independen secara individual dapat menerangkan variabel dependen. Hal ini dapat dilakukan dengan melihat prob $>$ chi $^{2}$ dari masing-masing variabel independen seperti yang tercantum dalam Tabel 2. Kriteria dalam uji statistik $\mathrm{z}$ ini adalah apabila hasil regresi menghasilkan p value $>0,05$, maka secara individual variabel dependen tersebut tidak berpengaruh terhadap variabel dependen. Namun sebaliknya, variabel independen secara individual berpengaruh terhadap variabel dependen.

Tabel 2 Hasil Pengujian Hipotesis

\begin{tabular}{cccc}
\hline Variable & Odds Ratio & Coef. & $\boldsymbol{P}$ \\
\hline KPA & 0,000000483 & $-14,54234$ & 0,203 \\
CS & 1,168892 & 0,1560566 & 0,453 \\
FD & 1,87995 & 0,6312452 & 0,010 \\
\hline
\end{tabular}

Variabel kompetisi pasar audit pada Tabel 2 dapat diartikan bahwa dengan tingkat keyakinan sebesar 95\%, p value sebesar 0,203 maka 0,203>0,05, sehingga H1 ditolak. Variabel client size memiliki p value sebesar 0,453 maka 0,453 > 0,05, sehingga $\mathbf{H 2}$ diterima. Variabel financial distress memiliki $\mathrm{p}$ value sebesar 0,010 maka 0,010<0,05, sehingga $\mathbf{H 3}$ diterima.

\section{Uji Serentak dengan Likelihood Ratio}

Likelihood ratio merupakan pengganti F-stat yang berfungsi untuk menguji apakah variabel independen (kompetisi pasar audit, client size, dan financial distress) secara bersama-sama mempengaruhi variabel dependen. Probabilitas likelihood ratio menunjukkan nilai sebesar 0,0373, dengan tingkat keyakinan sebesar 95\%, maka $0,0373<0,05$, sehingga ketiga variabel secara serentak mempengaruhi praktik shopping opinion.

\section{Goodnest of Fit Test dengan R-Square}

Uji goodness of fit bertujuan untuk melihat seberapa besar variasi dalam variabel dependen dapat dijelaskan secara bersama-sama oleh variabel dependen dan untuk melihat seberapa baik model penelitian yang digunakan dapat menjelaskan variabel dependen, maka statistik menggunakan $R$-square $\left(\mathrm{R}^{2}\right)$. Semakin tinggi nilai $R$-square, semakin baik pula model yang digunakan dalam penelitian. Model penelitian yang baik dianggap mampu menjelaskan variabel dependen. Oleh karena itu, nilai $R$-square yang tinggi sangat diharapkan dalam suatu penelitian.

Pada regresi logistik, parameter yang dilihat pada uji goodness of fit adalah Pseudo $R^{2}$. Pada output uji goodness of fit nilai Pseudo $R^{2}$ adalah sebesar 0,1019. Hal ini menunjukkan bahwa variabel independen hanya mampu menjelaskan 
variabel dependen sebesar 10 persen. Atau dengan kata lain, hanya 10 persen dari variasi variabel dependen yang dapat dijelaskan oleh model. Nilai Pseudo $R^{2}$ yang kecil tidak mengindikasikan bahwa suatu model dianggap tidak bagus. Nilai Pseudo $R^{2}$ yang bernilai antara 0 sampai dengan 1 bukan merupakan interpretasi yang alami, melainkan tiruan untuk mengganti $R$-square pada model logit (Greene, 2000). Hal tersebut didukung oleh Gujarati (2003) yang menyatakan bahwa hal-hal yang harus diperhatikan dalam model regresi logistik, yaitu indikator signifikansi model, signifikansi variabel-variabel independen dan arah koefisien dari variabel tersebut. Dari pernyataan tersebut dapat dikatakan bahwa nilai Pseudo $R^{2}$ tidak diutamakan.

\section{Pengaruh Kompetisi Pasar Audit terhadap Shopping Opinion}

Pada hasil uji parsial terhadap variabel kompetisi pasar audit dengan shopping opinion dihasilkan bahwa H1 ditolak. Hal tersebut berarti bahwa variabel kompetisi pasar audit tidak berpengaruh signifikan terhadap kecenderungan melakukan praktik shopping opinion. Penelitian ini tidak mendukung penelitian yang dilakukan oleh May (2016); Newton et al. (2016); Bleibtreu and Stefani (2018); Xue, Yao, and Wang (2018); Laksmiati and Atiningsih (2018) yang menyatakan bahwa dengan kompetisi pasar audit berpengaruh terhadap praktik shopping opinion. Xue, Yao, and Wang (2018) menjelaskan bahwa hal ini dapat terjadi karena persaingan yang tinggi antar KAP dapat mengakibatkan sulitnya KAP untuk mendapatkan klien, sehingga KAP cenderung mengikuti keinginan klien demi mempertahankan klien mereka. Selain itu, kompetisi pasar audit sangat relevan dengan shopping opinion karena persaingan yang meningkat akan meningkatkan probabilitas switching auditor. Switching auditor terjadi jika KAP sebelumnya memberikan opini yang tidak sesuai dengan keinginan klien, sehingga klien lebih memilih untuk mengganti dengan KAP yang akan memberikan opini yang lebih baik dari KAP sebelumnya. Laksmiati and Atiningsih (2018) menjelaskan bahwa perusahaan cenderung melakukan shopping opinion (mengganti auditor untuk mendapatkan opini lebih baik) ketika perusahaan berisiko mendapatkan opini audit going-concern.

Hasil penelitian ini menunjukkan bahwa perusahaan dapat memilih KAP mana yang sesuai dengan keinginan perusahaan, namun KAP tetap mempertahankan profesionalitasnya dalam memberikan jasa audit. Sehingga, biaya audit yang diberikan oleh perusahaan bukan untuk mendapatkan opini audit yang lebih baik tetapi karena cakupan pekerjaan yang memang lebih luas. Hal ini dapat dibuktikan bahwa perusahaan yang mengeluarkan biaya audit lebih tinggi merupakan perusahaan-perusahaan besar dan dalam kondisi keuangan yang baik. Sehingga dapat dirumuskan bahwa meskipun sampel KAP berada di kompetisi pasar audit yang tinggi, KAP tidak memanfaatkan situasi tersebut untuk mempermudah perusahaan memperoleh opini audit yang lebih baik dengan menawarkan biaya audit yang lebih tinggi.

\section{Pengaruh Client Size terhadap Shopping Opinion}

Pada hasil uji parsial terhadap variabel client size dengan shopping opinion dihasilkan bahwa $\mathbf{H 2}$ diterima. Hal tersebut dapat diartikan bahwa variabel client size tidak berpengaruh signifikan terhadap kecenderungan melakukan praktik shopping opinion. Penelitian ini mendukung hasil penelitian dari Winata and 
Anisykurlillah (2018) dan Darmayanti (2017) yang menyatakan bahwa ukuran perusahaan tidak berpengaruh secara signifikan terhadap praktik shopping opinion. Kemudian hasil penelitian ini tidak mendukung penelitian Laksmiati and Atiningsih (2018) yang menyatakan bahwa setiap perusahaan baik besar maupun kecil cenderung untuk patuh terhadap standar yang berlaku karena adanya regulasi yang mengharuskan untuk patuh terhadap standar. Selain itu perusahaan cenderung melakukan shopping opinion jika perusahaan memiliki kemungkinan besar untuk mendapatkan opini audit going-concern karena hal tersebut dapat mempengaruhi pihak stakeholder secara lebih signifikan. Hal ini disebabkan opini audit going-concern mengindikasikan adanya masalah keberlangsungan usaha dalam perusahaan. Berdasarkan data penelitian hanya $6,58 \%$ atau 5 perusahaan yang memperoleh opini audit going-concern.

\section{Pengaruh Financial Distress terhadap Shopping Opinion}

Pada hasil uji parsial terhadap variabel financial distress dengan shopping opinion dihasilkan bahwa $\mathbf{H 3}$ diterima. Hal tersebut dapat diartikan bahwa financial distress berpengaruh positif signifikan terhadap kecenderungan melakukan praktik shopping opinion. Penelitian ini sejalan dengan penelitian yang dilakukan oleh Suyono, Yi, and Riswan (2013); Manto and Wanda (2018); Kurnia and Mella (2018); Winata and Anisykurlillah (2018). Suyono, Yi, and Riswan (2013) menjelaskan bahwa perusahaan yang mengalami financial distress atau masalah keuangan cenderung mengganti KAP dibandingkan perusahaan yang lebih sehat, karena perusahaan ini perlu menggunakan KAP dengan kualitas yang lebih baik demi mempertahankan citra perusahaan di mata investor dan pengguna laporan keuangan. Manto and Wanda (2018) menyatakan bahwa perusahaan yang mengalami financial distress atau masalah keuangan lebih cenderung mengganti KAP dibandingkan dengan perusahaan yang lebih sehat karena perusahaan seperti ini perlu menggunakan KAP dengan kualitas yang lebih tinggi untuk mempertahankan citra baik perusahaan dimata investor. Kurnia and Mella (2018) menjelaskan bahwa perusahaan yang mengalami financial distress melakukan praktik shopping opinion untuk menghindari mendapatkan opini audit goingconcern. Winata and Anisykurlillah (2018) menyatakan bahwa perusahaan berukuran besar cenderung memiliki kondisi keuangan yang sehat dan cenderung untuk melakukan praktik shopping opinion untuk mempertahankan reputasi perusahaan.

\section{KESIMPULAN}

Kondisi kompetisi pasar audit tinggi perusahaan cenderung tidak melakukan praktik shopping opinion. Besar atau kecilnya ukuran perusahaan, perusahaan lebih cendrung tidak melakukan praktik shopping opinion. Sedangkan perusahaan yang mengalami kondisi keuangan yang sehat cenderung melakukan praktik shopping opinion.

Implikasi dari temuan ini adalah regulator perlu membuat regulasi yang mengatur atau membatasi adanya shopping opinion khususnya pada kondisi kompetisi pasar audit yang rendah. Hal ini dilakukan agar opini audit yang diberikan benar-benar menunjukkan kualitas audit yang telah dijalankan. Selain itu para pengguna laporan keuangan khususnya auditor dan investor perlu berhati- 
hati dalam menginterpreasikan opini audit pada perusahaan yang mengalami masalah keuangan (financial distress), karena bisa jadi opini tersebut tidak menunjukkan kondisi laporan keuangan perusahaan yang sebenarnya. Keterbatasan penelitian adalah menggunakan data sekunder yang disajikan pada laporan keuangan perusahaan manufaktur, sehingga tidak mampu digeneralisir untuk jenis industri yang lain.

Rekomendasi untuk penelitian selanjutnya adalah memperpanjang periode penelitian dan menambah jenis industri yang digunakan sehingga hasil yang diperoleh mampu digeneralisir untuk seluruh perusahaan. Selain itu peneliti juga dapat menggunakan variabel lain baik dari sisi internal maupun eksternal perusahaan seperti karakeristik top manajemen perusahaan, kecenderungan manipulasi laporan keuangan, reputasi kantor akuntan publik dan regulasi yang mengatur pergantian kantor akuntan publik.

\section{DAFTAR PUSTAKA}

Achyarsyah, Padri. 2016. "The Analysis of the Influence of Financial Distress, Debt Default, Company Size, and Leverage on Going Concern Opinion1." International Journal of Applied Business and Economic Research 14 (10): 6767-83. http://repository.unas.ac.id/62/1/7. Padri Achyarsyah.pdf.

Afriansyah, Zef, and Sylvia Veronica Nalurita Purnana Siregar. 2010. "Konsentrasi Pasar Audit Di Indonesia (Analisis Empiris Di Pasar Modal Indonesia)." Simposium Nasional Akuntansi X Makassar, no. July 2007: $1-27$. https://www.researchgate.net/profile/ZefArfiansyah/publication/344363020_Konsentrasi_pasar_audit_di_Indonesia _Analisis_empiris_di_pasar_modal_Indonesia/links/5f6c6d3c299bf1b53ee dd91c/Konsentrasi-pasar-audit-di-Indonesia-Analisis-empiris-di-pasarmodal-In.

Altman, Edward I. 1968. "Financial Ratios, Discriminant Analysis and the Prediction of Corporate Bankruptcy." The Journal of Finance 23 (4): 589609. https://doi.org/10.2307/2978933.

Anggraita, Viska, Fitriany Fitriany, Sandra Aulia, and Arywati Arywati. 2016. "Pengaruh Persaingan Pasar Jasa Audit Terhadap Kualitas Audit: Peranan Regulasi Rotasi Dan Regulasi Corporate Governance." TEKUN: Jurnal Telaah Akuntansi Dan Bisnis 1 (7): 23-34. https://scholar.ui.ac.id/en/publications/pengaruh-persaingan-pasar-jasaaudit-terhadap-kualitas-audit-pera.

Ardi, Frans Guntara, Indra Saputra, and Susi Dwi Mulyani. 2019. "Pengaruh Financial Distress, Ukuran Perusahaan, Audit Tenure Dan Reputasi Auditor Terhadap Opini Audit Modifikasi Going Concern.” Jurnal $\begin{array}{lllll}\text { Magister Akuntansi Trisakti } 6 & \text { (2): }\end{array}$ https://doi.org/10.25105/jmat.v6i2.5557.

Bleibtreu, Christopher, and Ulrike Stefani. 2018. "The Effects of Mandatory Audit Firm Rotation on Client Importance and Audit Industry Concentration." The Accounting Review 93 (1): 1-27. https://doi.org/10.2308/accr-51728.

Bryan, Daniel, Guy Dinesh Fernando, and Arindam Tripathy. 2013. "Bankruptcy 
Risk, Productivity and Firm Strategy." Review of Accounting and Finance 12 (4): 309-26. https://doi.org/10.1108/RAF-06-2012-0052.

Carcello, Joseph V., and Albert L. Nagy. 2004. "Audit Firm Tenure and Fraudulent Financial Reporting." AUDITING: A Journal of Practice \& Theory 23 (2): 55-69. https://doi.org/10.2308/aud.2004.23.2.55.

Chen, Feng, Jere R. Francis, and Yu Hou. 2017. "Opinion Shopping through Same-Firm Audit Office Switches." Ssrn. https://doi.org/10.2139/ssrn.2899888.

Chen, Feng, Songlan Peng, Shuang Xue, Zhifeng Yang, and Feiteng Ye. 2015. "Do Audit Clients Successfully Engage in Opinion Shopping? PartnerLevel Evidence." Journal of Accounting Research 54 (1): 79-112. https://doi.org/10.1111/1475-679X.12097.

Chung, Heesun, Catherine Heyjung Sonu, Yoonseok Zang, and Jong-Hag Choi. 2019. "Opinion Shopping to Avoid a Going Concern Audit Opinion and Subsequent Audit Quality." AUDITING: A Journal of Practice \& Theory 38 (2): 101-23. https://doi.org/10.2308/ajpt-52154.

Darmayanti, Novi. 2017. "The Effect of Audit Opinion, Financial Distress, Client Size, Management Turn and KAP Size on Auditor Switching." Journal of Economics, Business \& Accountancy Ventura 20 (2): 237-48. https://doi.org/10.14414/jebav.v20i2.1125.

DeAngelo, Linda Elizabeth. 1981. "Auditor Independence Low Balling and Disclosure Regulations." Journal of Accounting and Economics 3 (2): 113-27. https://doi.org/10.1016/0165-4101(81)90009-4.

Fachruddin, Wan, and Sri Handayani. 2017. "Pengaruh Fee Audit, Pengalaman Kerja, Dan Independensi Auditor Terhadap Kualitasaudit Pada Kantor Akuntan Publik Di Kota Medan.” Jurnal Akuntansi Dan Bisnis 3 (2): 14455. http://ojs.uma.ac.id/index.php/jurnalakundanbisnis/article/view/1234.

Fathi, Jouini. 2013. "The Determinants of the Quality of Financial Information Disclosed by French Listed Companies." Mediterranean Journal of Social Sciences $\quad 4 \quad$ (2): 319-36. http://www.richtmann.org/journal/index.php/mjss/article/view/218.

Huang, Ting Chiao, Hsihui Chang, and Jeng Ren Chiou. 2016. "Audit Market Concentration, Audit Fees, and Audit Quality: Evidence from China." Auditing 35 (2): 121-45. https://doi.org/10.2308/ajpt-51299.

Jensen, Michael C., and William H. Meckling. 1976. "Theory of the Firm: Managerial Behavior, Agency Costs and Ownership Structure." Journal of Financial Economics (JFE) 3 (4): 77-132. https://doi.org/10.2139/ssrn.94043.

John, Ayoola Tajudeen, and Obokoh lawrence Ogechukwu. 2018. "Corporate Governance and Financial Distress in the Banking Industry: Nigerian Experience." Journal of Economic and Behavioral Studies 10 (1): 182-93. https://doi.org/10.22610/jebs.v10i1(J).2101.

Kurnia, Pipin, and Nanda Fito Mella. 2018. "Opini Audit Going Concern.” Jurnal Riset Akuntansi Dan Keuangan 6 (1): 105-22. https://ejournal.upi.edu/index.php/JRAK/article/view/8937.

Laksmiati, Elsa Devi, and Suci Atiningsih. 2018. "Pengaruh Auditor Switching, Reputasi KAP Dan Financial Distress Terhadap Opini Audit Going Concern." Fokus Ekonomi: Jurnal Ilmiah Ekonomi 13 (1): 45-61. 
https://ejournal.stiepena.ac.id/index.php/fe/article/view/178.

Manto, Juli Is, and Dewi Lesmana Wanda. 2018. "Pengaruh Financial Distress, Pergantian Manajemen Dan Ukuran KAP Terhadap Auditor Switching." Media Riset Akuntansi, Auditing \& Informasi 18 (1): 205-24. https://doi.org/10.25105/mraai.v18i2.3212.

May, Amy. 2016. "Audit Market Concentration, Auditor Switching and Audit Fee Pricing: An Investigation of the UK Private Company Audit Market, 20052012." University of Leeds. https://etheses.whiterose.ac.uk/16012/.

Newton, Nathan J., Julie S. Persellin, Dechun Wang, and Michael S. Wilkins. 2016. "Internal Control Opinion Shopping and Audit Market Competition." The Accounting Review 91 (2): 603-623. https://doi.org/10.2308/accr-51149.

Ouyang, Bo, and Huishan Wan. 2013. "Does Audit Tenure Impair Auditor Independence? Evidence from Option Backdating Scandals." International Journal of Business and Social Science 4 (14): 23-33. https://ijbssnet.com/journal/index/2192.

Sangkrista, Louis Bernardus Dupa, and Fitriany Fitriany. 2017. "Impact of Abnormal Audit Fee on Audit Opinion." In Proceedings of the 6th International Accounting Conference (IAC 2017), 55:254-59. Atlantis Press. https://doi.org/10.2991/iac-17.2018.45.

Su, Xijia. 2009. "Auditor-Client Interdependence and Audit Quality: PartnerLevel Evidence." In CAAA Annual Conference 2009 Paper. SSRN Elsevier. https://doi.org/10.2139/ssrn.1325647.

Suyono, Eko, Feng Yi, and Riswan Riswan. 2013. "Determinant Factors Affecting The Auditor Switching: An Indonesian Case." Global Review of Accounting and Finance 4 (2): 103-16.

Winata, Atika Sukma, and Indah Anisykurlillah. 2018. "Analysis of Factors Affecting Manufacturing Companies in Indonesia Performing a Switching Auditor." Jurnal Dinamika Akuntansi 9 (1): 82-91. https://doi.org/10.15294/jda.v9i1.11998.

Xue, Shuang, Youfu Yao, and Xuefang Wang. 2018. "Concentration of The Supply Chain and Audit Opinion Shopping: The Case of China." China Journal of Accounting Studies 6 (2): 135-58. https://doi.org/10.1080/21697213.2018.1521955.

Yakubu, Rahman, and Tracey Williams. 2020. "A Theoretical Approach to Auditor Independence and Audit Quality." Corporate Ownership and Control 17 (2): 124-41. https://doi.org/10.22495/cocv17i2art11. 